ISBN 978-93-84468-92-7

International Conference on Issues in Education, Literature, Humanities and Social Sciences

(IELHSS-2017)

Kuala Lumpur (Malaysia) Jan. 4-5, 2017

\title{
The factors that attract Chinese People to work in Thailand
}

\author{
Dr. Chairat Suriyaarpa, and Luxia Wu \\ Postgraduate school of business Administration \\ Kasembundit University, Bangkok
}

\begin{abstract}
The purpose of this study "The factors that attract Chinese people to work in Thailand" is to investigate the factors that attract Chinese people to work in Thailand .It used 385 questionnaires to do the survey. The statistical analysis data were percentage and mean, standard deviation, and comparison of relationships between variables by T-test, F-test, One Way ANOVA, and Regression Analysis.

The study found that most of the respondents were female, aged between 21-30 years old, undergraduate degree, occupation of Chinese teachers, monthly income in 20001-30000 baht. More than 3 years of working experience in Thailand, most of them are from Guangxi province, located in central Thailand, most of them are married. Respondents' age, income, and place of origin in Thailand vary greatly depending on their job satisfaction in Thailand.

There are several important factors that attract Chinese people to work in Thailand: a safe working environment; provide a level playing field and the leadership of recognition. These factors are also affect the satisfaction of Chinese people who are work in Thailand. The results show that Administrative officers should pay attention to the work environment safety, give enough recognition and affirmation to employees, and provide fair competitive opportunities for employees. To improve staff's motivation and satisfaction.
\end{abstract}

Keywords: factors work

\section{Introduction}

Presently, Thailand and China have exchange educational for under graduate student's program type 1:1 meaning that each year there are 10,000 of Thai students and 10,000 Chinese students (numbers fictional) for example, take academic courses for two years in their own country and another two years at the affiliated university in foreign country, the choices of the university that they will receive are from the drawings. Therefore, Chinese students are spread all over universities in Thailand. It is known to the world that Chinese's economy has been growing continuously and because of the financial success many students choose to study abroad. Currently there are more Chinese working in Thailand for many reasons, such as it is a Buddhist country, friendly, welcome foreigners, open for opinions and religion, growing economy continuously, strong export, lot of natural resources, labors with skills, clearly government investment policy, etc.

From introduction above, the researcher are interested in determining of factors influencing Chinese labors to work in Thailand and results from the study will be used as a guideline for administrative officers of the corporation to improve the strategy to prepare for Chinese labors in Thailand.

\section{The Purpose of the Study}

To study the satisfaction and motivation factors influencing Chinese workers working in Thailand. Conceptual framework of the study 


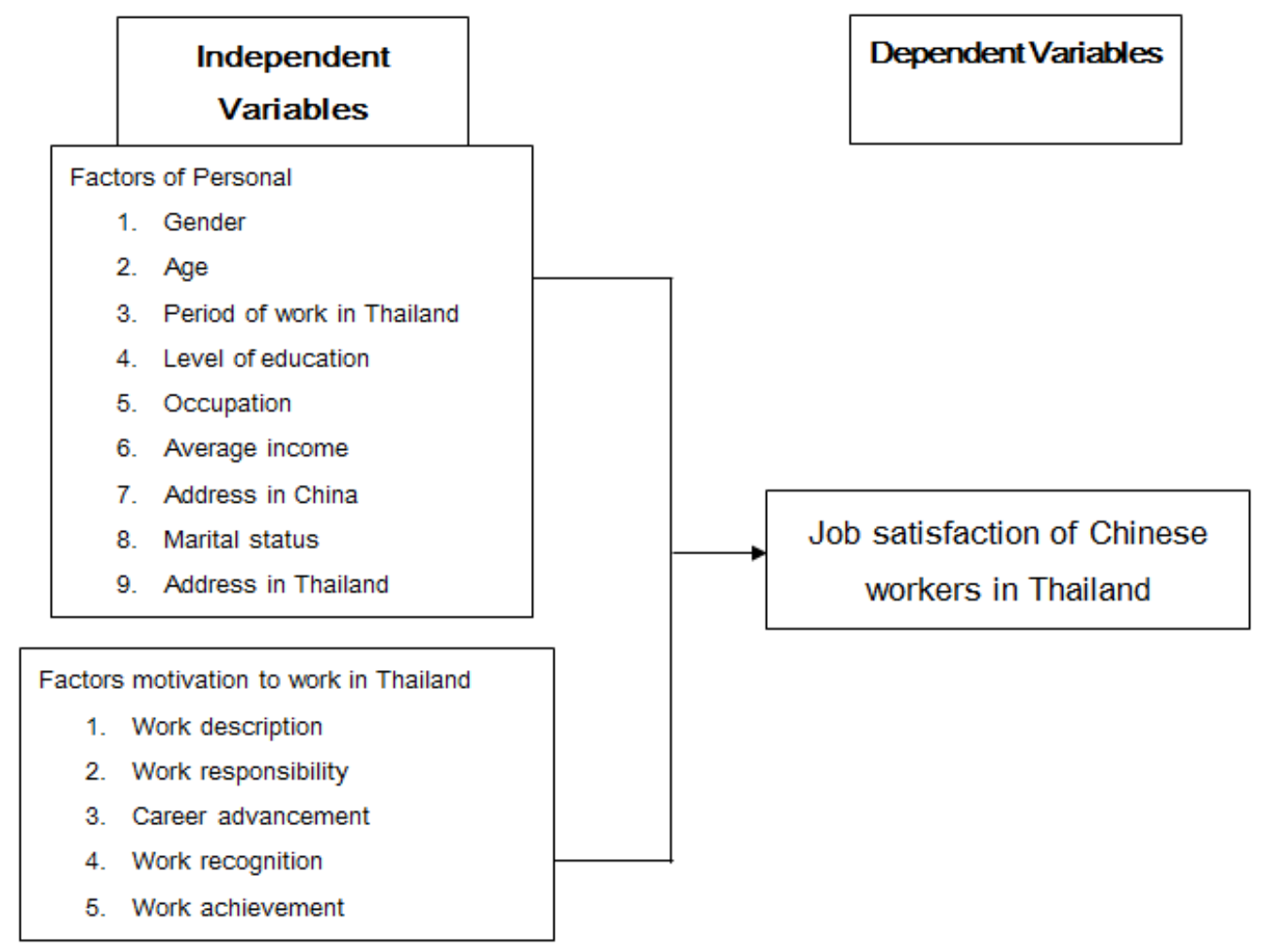

\section{Sample of selection}

The samples were 385 Chinese workers who work in Thailand.

\section{Data collection procedure}

The questionnaires were distributed to sample of 385 Chinese workers who work in Thailand. A total of 385 usable questionnaires were returned back to the researcher, yielding a 100 percent response rate and no missing data.

TABLE I: shows comparison between the personal different such as gender was not affecting the work satisfaction of Chinese workers in Thailand.

\begin{tabular}{|c|c|c|c|c|c|c|}
\hline Gender & Mean & S.D. & $\mathrm{t}$ & $\mathrm{df}$ & Sig. & Results \\
\hline Male & 3.67 & 0.141 & 0.09 & 383 & 0.92 & No different \\
\hline female & 3.66 & 0.146 & & & & \\
\hline
\end{tabular}

*Significant level 0.05

From table 1: The test of hypothesis with t-test at significant level 0.05 revealed that factors of personal different such as gender influencing work satisfaction of Chinese workers in Thailand at significant 0.92 greater than 0.05 level which accepted main hypothesis $\mathrm{H} 0$ results the personal different such as gender was not affecting the work satisfaction of Chinese workers in Thailand.

TABLE II: shows comparison between the personal different such as age affected the work satisfaction of Chinese

\begin{tabular}{|l|c|c|c|c|c|c|}
\multicolumn{1}{|c}{ Workers in Thailand. } \\
\hline \multicolumn{1}{|c|}{ Work satisfaction } & SS & df & MS & f & Sig. & results \\
\hline Between group & 4.878 & 3 & 3.526 & 4.396 & $0.005^{*}$ & different \\
\hline Within group & 171.6 & 381 & 0.802 & & & \\
\hline Total & 182.220 & 384 & & & & \\
\hline
\end{tabular}

*Significant level 0.05 
From table 2: The test of hypothesis with one-way Anova at significant level 0.05 revealed that factors of personal different such as age influencing work satisfaction of Chinese workers in Thailand at significant 0.005 less than 0.05 level which accepted main hypothesis $\mathrm{H} 1$ results the personal different such as age affected the work satisfaction of Chinese workers in Thailand.

TABLE III: shows comparison between the personal different such as period of work in Thailand was not affected the work satisfaction of Chinese workers in Thailand.

\begin{tabular}{|l|c|c|c|c|c|c|}
\hline \multicolumn{1}{|c|}{ Work satisfaction } & SS & df & MS & f & Sig. & results \\
\hline Between group & 4.978 & 3 & 1.625 & 2.151 & 0.097 & $\begin{array}{l}\text { No } \\
\text { different }\end{array}$ \\
\hline Within group & 160.787 & 381 & 0.757 & & & \\
\hline Total & 166.665 & 384 & & & & \\
\hline
\end{tabular}

*Significant level 0.05

From table 3: The test of hypothesis with one-way Anova at significant level 0.05 revealed that factors of personal different such as period of work in Thailand influencing work satisfaction of Chinese workers in Thailand at significant 0.097 greater than 0.05 level which accepted main hypothesis $\mathrm{H} 0$ results the personal different such as period of work in Thailand was not affected the work satisfaction of Chinese workers in Thailand.

TABLE IV: shows comparison between the personal different such as level of education was not affected the work satisfaction of Chinese workers in Thailand.

\begin{tabular}{|l|c|c|c|c|c|c|}
\hline \multicolumn{1}{|c|}{ Work satisfaction } & SS & df & MS & f & Sig. & results \\
\hline Between group & 5.435 & 3 & 1.812 & 2.404 & 0.069 & No different \\
\hline Within group & 161.230 & 381 & 0.753 & & & \\
\hline Total & 166.665 & 384 & & & & \\
\hline
\end{tabular}

*Significant level 0.05

From table 4: The test of hypothesis with one-way Anova at significant level 0.05 revealed that factors of personal different such as level of education influencing work satisfaction of Chinese workers in Thailand at significant 0.069 greater than 0.05 level which accepted main hypothesis H0 results the personal different such as level of education was not affected the work satisfaction of Chinese workers in Thailand.

TABLE V: shows comparison between the personal different such as occupation was not affected the work satisfaction of Chinese workers in Thailand.

\begin{tabular}{|l|c|c|c|c|c|c|}
\hline \multicolumn{1}{|c|}{ Work satisfaction } & SS & df & MS & f & Sig. & results \\
\hline Between group & 5.218 & 3 & 1.739 & 2.305 & 0.078 & No different \\
\hline Within group & 161.448 & 381 & 0.754 & & & \\
\hline Total & 166.665 & 384 & & & & \\
\hline
\end{tabular}

*Significant level 0.05

From table 5: The test of hypothesis with one-way Anova at significant level 0.05 revealed that factors of personal different such as occupation influencing work satisfaction of Chinese workers in Thailand at significant 0.078 greater than 0.05 level which accepted main hypothesis $\mathrm{H} 0$ results the personal different such as occupation was not affected the work satisfaction of Chinese workers in Thailand.

TABLE VI: shows comparison between the personal different such as average income affected the work satisfaction of Chinese workers in Thailand

\begin{tabular}{|l|c|c|c|c|c|c|}
\hline \multicolumn{1}{|c|}{ Work satisfaction } & SS & df & MS & f & Sig. & results \\
\hline Between group & 13.793 & 3 & 4.598 & 6.436 & $0.000^{*}$ & Different \\
\hline Within group & 152.873 & 381 & 0.714 & & & \\
\hline Total & 166.665 & 384 & & & & \\
\hline
\end{tabular}

*Significant level 0.05 
From table 6: The test of hypothesis with one-way Anova at significant level 0.05 revealed that factors of personal different such as average income influencing work satisfaction of Chinese workers in Thailand at significant 0.00 less than 0.05 level which accepted main hypothesis $\mathrm{H} 1$ results the personal different such as average income affected the work satisfaction of Chinese workers in Thailand.

TABLE VII: shows comparison between the personal different such as information in china affected the work satisfaction of Chinese workers in Thailand

\begin{tabular}{|c|c|c|c|c|c|c|}
\hline Work satisfaction & SS & df & MS & f & Sig. & results \\
\hline Between group & 34.85 & 4 & 8.713 & 13.470 & $0.000^{*}$ & Different \\
\hline Within group & 137.77 & 380 & 0.646 & & & \\
\hline Total & 172 & 384 & & & & \\
\hline
\end{tabular}

*Significant level 0.05

From table 7: The test of hypothesis with one-way Anova at significant level 0.05 revealed that factors of personal different such as information in china influencing work satisfaction of Chinese workers in Thailand at significant 0.00 less than 0.05 level which accepted main hypothesis $\mathrm{H} 1$ results the personal different such as information in china affected the work satisfaction of Chinese workers in Thailand.

TABLE VIII: shows comparison between the personal different such as marital status was not affected the work satisfaction of Chinese workers in Thailand.

\begin{tabular}{|l|c|c|c|c|c|c|}
\hline \multicolumn{1}{|c|}{ Work satisfaction } & SS & df & MS & f & Sig. & results \\
\hline Between group & 7.978 & 3 & 2.659 & 2.251 & 0.058 & No different \\
\hline Within group & 157.787 & 381 & 0.737 & & & \\
\hline Total & 166.665 & 384 & & & & \\
\hline
\end{tabular}

*Significant level 0.05

From table 8: The test of hypothesis with one-way Anova at significant level 0.05 revealed that factors of personal different such as marital status influencing work satisfaction of Chinese workers in Thailand at significant 0.058 greater than 0.05 level which accepted main hypothesis $\mathrm{H} 0$ results the personal different such as marital status was not affected the work satisfaction of Chinese workers in Thailand.

TABLE IX: shows comparison between the personal different such as information in Thailand affected the work satisfaction of Chinese workers in Thailand

\begin{tabular}{|l|c|c|c|c|c|c|}
\hline \multicolumn{1}{|c|}{ Work satisfaction } & SS & df & MS & f & Sig. & results \\
\hline Between group & 33.10 & 4 & 8.270 & 12.633 & $0.000^{*}$ & different \\
\hline Within group & 139.5 & 380 & 0.655 & & & \\
\hline Total & 172 & 384 & & & & \\
\hline
\end{tabular}

*Significant level 0.05

From table 9: The test of hypothesis with one-way Anova at significant level 0.05 revealed that factors of personal different such as information in Thailand influencing work satisfaction of Chinese workers in Thailand at significant 0.00 less than 0.05 level which accepted main hypothesis $\mathrm{H} 1$ results the personal different such as information in Thailand affected the work satisfaction of Chinese workers in Thailand.

\section{Summary of Study Results}

Findings indicated that most of 385 respondents who came from Guangxi were females, age 20-30 years old, period of work in Thailand over 3 years, bachelor degree graduated, Chinese language teachers, average monthly income 20,000-30,000 baht, living in Bangkok, motivation factors were job description, safety working environment, career advancement opportunity, occupation recognition and trusted by supervisors which correlated to work satisfaction of Chinese workers in Thailand. 


\section{Suggestions for Future Research}

For the future study, researcher should find more information by in-depth interviews to every personnel in all levels by choosing a representative of each group, including administrative officers, and study motivation factors influencing Chinese teachers choosing to work in Thailand in order to confirm the accuracy of the results obtained from this study.

\section{References}

[1] Kraingsak Keawying. (2550). Haman resources management. Secretary of Ministry. Expert net. Bangkok.

[2] Kusuma Jaroonsukapimol. (2552). Work performance motivation of operational level of sales and services employees of T.O.T. Co., Ltd., public company, Thesis, Master of Business Administration, Thonburi University.

[3] Jirattikarn Boonrod. (2553). Behavior and influencing factors of employees in determining to Work for factory industry in Amata Nakorn industrial estate, Cholburi province. Kasetsart University.

[4] Chalee Prungprakon. (2555). Work performance motivator factors of police civil servants at Kumuang police station, Burirum province. Ratchapath Burirum University.

[5] Preeyapan Laongnual. (2550). Work motivation of employees at Ratchaphat Northeastern Isan University. Thesis, Ratchaphat Ubonratchatani University.

[6] Phongpit Ruksatam. (2553). Work motivation of teacher personnel at Cholburi capital district, Thesis, Burapha University.

[7] Monton Roytrakul. (2546). Work motivation performance of revenue services employees area branch. Thesis, Ratchaphat Nakorn Pathom University.

[8] Monrudee Kritkraingkrai. (2547). Work satisfaction behavior of personnel at Electro Chemical Technology Co., Ltd., Thesis, Srinakarinviroj University.

[9] Vatchara Boonplod. (2551). Work motivation of personnel at Administration Organization in Payao province, Thesis, Master of Business Administration, Khonkaen University.

[10] Varaporn Kampethdee. (2552). Work motivation performance of revenue services employees Area branch, Ubonratchatani. Thesis, Ratchaphat Ubonratchatani University.

[11] Srianun Sridangarm. (2550). Motivation and work achievement of personnel at Tambon Administrative Organization, Piboonmungsaharn district, Independent Study, Khonkaen University.

[12] Supop Kantima. (2550). Work performance motivation of employees at Chiengmai Municipality. Independent Study, Chiengmai University. 